have been, used by a group of non-native residents in that country, and what is the past and present incidence of malaria in this group.

The group was composed of all the non-native residents in Nigeria who reported to my out-patient clinic between November 1, 1951, and March 31, 1952.

The following antimalarial drugs were being used at the time these patients were interviewed: proguanil by $68 \%$; quinine by $16 \%$; mepacrine by $6 \%$; chloroquine by $2 \%$. Of the whole group, $6 \%$ admitted to being, or were known to be, intermittent in their habits. One individual did not take any antimalarial drug.

Among the adults who had taken only one antimalarial drug daily with regularity since starting to live in Nigeria, a past history of malaria was reported as follows: those taking $100 \mathrm{mg}$. of proguanil, $15 \%$; $200 \mathrm{mg}$. of proguanil, $0 \%$; $100 \mathrm{mg}$. of mepacrine, $17 \%$; 4 or 5 gr. ( 260 or $320 \mathrm{mg}$.) of quinine, $50 \%$. Chloroquine in doses of $300 \mathrm{mg}$. twice or thrice weekly had been taken regularly by three individuals, none of whom reported having had malaria.

The overall incidence of malaria in the group at the time of interview was found to be $11 \%$, of which total $10.9 \%$ occurred in those 10 years of age and over and $12.2 \%$ in children below this age. Excluding all individuals self-admittedly irregular takers of any antimalarial drug, the incidence of malaria was found to be $9 \%$, and if children are excluded the incidence in adults 20 years of age and over was $8 \%$.

It is concluded that the most satisfactory prophylactic to use at the present time against the subtertian malaria endemic in Nigeria is proguanil, taken in doses of 200 $\mathrm{mg}$. daily by those 10 years of age and over and $50 \mathrm{mg}$. daily for babies under 1 year. Quinine in doses of 1 to $1 \frac{1}{2}$ gr. (65 to $100 \mathrm{mg}$.) daily is a satisfactory suppressive for infants.

I am indebted to the Inspector-General of Medical Services, Nigeria, for permission to publish this paper.

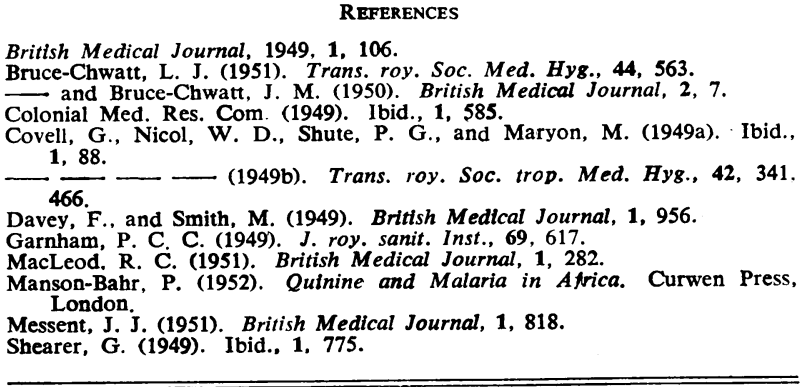

The perennial problem of over-population is again stressed in the report for' 1951 of the health conditions in the Maltese Islands and of the work of the Medical and Health Department, which was published recently. Cardiac conditions and cerebral vascular accidents accounted for the highest proportion of deaths, the figures being 148 and 102 per 1,000 respectively. Research is being carried out on the radical cure of malignant growths; deaths from this cause increased during the year under review. Progress is reported in the fight against tuberculosis: a good proportion of the population is being radiographed, and the incidence of the disease has shown a considerable decrease. An attempt has been made to integrate the laboratory services in Malta, which are at present divided into several sections and spread over a wide area. All this and much more information is contained in the report, which is available from the office of the Chief Government Medical Officer, Malta.

\section{FEMALE FERTILITY}

BY

DEREK LLEWELLYN-JONES, M.B., B.Ch., M.A.O. Obstetrician, General Hospital, Kuala Lumpur, Malaya; Late Registrar, Hope Hospital, Salford, Lancashire

In 1866 Matthews Duncan noted that "whilst a large number [of women] are fertile for a first time in each of the first three years of married life, only $7 \%$ of the fertile bear children after three years of marriage." From this it has been concluded by most British authors that sterility should be investigated after three years of marriage. In the United States of America most of the gynaecological textbooks suggest that two years of potentially fertile coitus should elapse before investigation. This may well be due to the work of Pearl (1939), who concluded, after investigating the case records of 199 white American women, that it took a woman, on an average, 24 months to conceive.

Recent editions of American and British textbooks voice this confusion. Four give four years as the time which should elapse before investigation of sterility, five give three years, three give two years, and two give one year. The others give no time. It is noted that those writers who have made a special study of the problem tend to investigate infertility after a shorter time than the others. As an example of this, Meaker's (1934) definition of infertility may be quoted. He defines sterility as "the inability to initiate the reproductive process on the part of a couple who have desired and attempted to reproduce for a reasonable length of time, ordinarily at least one year."

The incidence of infertile couples is estimated variously as between 8.5 and $15 \%$ of all marriages. In these unsettled times it becomes more important to determine the average length of time between the desire to conceive and the actual conception, so that those who exceed this average may be investigated with the minimum of delay. For nowadays, with poor housing conditions, voluntary contraception, occupations which entail longer or shorter periods of separation of the couple, later age of marriage, and impending separation for military reasons, those who are anxious to conceive should be helped as much as possible. As time passes and a woman still finds herself barren, much marital unhappiness and stress (which Stallworthy (1948) contends is itself a factor in infertility) accrues, and it is little comfort to her to be told by her doctor to "go away and don't worry, for you are still young."

That the fertility of a woman is related to her age has been believed from the time of Matthews Duncan onwards. In his investigations in Glasgow in 1866 he found that while $90 \%$ of women between the age of 20 and 24 would conceive for a first time within two years of marriage, only $63 \%$ of women between the ages of 30 and 34 and only $15 \%$ of women between the ages of 40 and 44 would do so. The Royal Commission on Population (1949) also gives interesting figures regarding the decline of fertility and the duration of marriage. It appears that the risk of conception in the second five years of marriage is reduced to about $50 \%$ of the risk in the first five years, and is again halved in the third five years.

\section{Fertility in Salford}

This survey was therefore undertaken in order to determine the average interval between the desire to conceive 
and the conception itself. All the patients were primigravidae attending the antenatal clinics of Hope Hospital, Salford, between August 1, 1950, and June 1, 1951. In all, 1,202 women were interviewed. If conception had occurred within nine months no further questions were asked regarding coital habits, contraceptive technique, or absence of the husband from home. But when conception had been delayed for a longer period than this, all these points were studied and allowance was made for them. Later all the women were examined physically and further questions were asked as a check. In 136 cases $(11.3 \%$ of the total) contraception or coitus interruptus had been practised for longer or shorter periods, and the calculation was made from the date of abandoning these methods and desiring to conceive. There is no evidence to show that contraception, by whatever method used by these women, is harmful to fertility.

The results of the survey are shown in the Table. If women who conceived prenuptially are included it can be seen that $90.25 \%$ of those studied were pregnant within

\begin{tabular}{|c|c|c|c|c|c|c|c|c|}
\hline \multirow{2}{*}{$\begin{array}{l}\text { Desire-to- } \\
\text { Conception } \\
\text { Interval } \\
\text { in Months }\end{array}$} & \multicolumn{6}{|c|}{ Age at Time of Desiring to Conceive } & \multirow{2}{*}{$\begin{array}{c}\% \\
\text { Preg- } \\
\text { nant }\end{array}$} & \multirow[b]{2}{*}{ Total } \\
\hline & $15-19$ & $20-24$ & $25-29$ & $30-34$ & $35-39$ & $\begin{array}{c}40 \text { and } \\
\text { Over }\end{array}$ & & \\
\hline $\begin{array}{r}\text { Prenuptial con- } \\
\text { ceptions } \\
0-3 \\
3-6 \\
6-9 \\
9-12 \\
12-18 \\
18-24 \\
24-36 \\
36+\end{array}$ & $\begin{array}{r}86 \\
54 \\
26 \\
5 \\
2 \\
0 \\
0 \\
0 \\
0\end{array}$ & $\begin{array}{r}96 \\
263 \\
116 \\
52 \\
40 \\
10 \\
5 \\
5 \\
5\end{array}$ & $\begin{array}{r}18 \\
112 \\
62 \\
32 \\
27 \\
10 \\
7 \\
12 \\
24\end{array}$ & $\begin{array}{r}7 \\
20 \\
13 \\
15 \\
5 \\
6 \\
8 \\
2 \\
19\end{array}$ & $\begin{array}{l}4 \\
3 \\
3 \\
6 \\
7 \\
1 \\
0 \\
0 \\
6\end{array}$ & $\begin{array}{l}0 \\
3 \\
1 \\
2 \\
2 \\
0 \\
0 \\
0 \\
0\end{array}$ & \begin{tabular}{|c}
17.5 \\
38.0 \\
18.5 \\
9.25 \\
7.0 \\
2.25 \\
1.5 \\
1.5 \\
4.5
\end{tabular} & $\begin{array}{r}211 \\
455 \\
221 \\
112 \\
83 \\
27 \\
20 \\
19 \\
54\end{array}$ \\
\hline & 173 & 592 & 304 & 95 & 30 & 8 & 100 & 1,202 \\
\hline
\end{tabular}

one year of desiring to conceive, $92.5 \%$ were pregnant within 18 months, and $94.0 \%$ were pregnant within 24 months. In other words, only four more women in every hundred had conceived after two years than had conceived within one year.

It may be objected that the prenuptial conceptions should not be included. But since almost half of such conceptions occurred to girls between 15 and 19 years and almost all to girls under 25 , it can surely be argued that these have rarely practised coitus consistently and without contraception for more than one year. When questioned, most of these girls said that coitus had occurred only during the two months before the first missed period. The figure of $17.5 \%$ of first prenuptial conceptions is reasonably close to that of $16.0 \%$ given for the country as a whole by the Registrar-General in 1938-9.

\section{Comparison with Other Surveys}

In 1946 Scott Russell, working at Oxford, surveyed 293 women, of whom 197 were primigravid and 96 multigravid. In his paper it is not noted whether any of the conceptions were prenuptial, but it is assumed that there is little difference in morals between Salford and Oxford, and that unless questioned directly on this point most women who conceived prenuptially will say that they conceived directly after marriage. It is thought that this may be the reason for the high figure of conceptions noted by Scott Russell to have occurred after marriage but before there had been a menstrual period. He found that of 162 primigravidae, $56(35.1 \%)$ conceived within a month of marriage, 51 $(31.5 \%)$ conceived within three months, and a further $19.1 \%$ had conceived within the first year. Thus $87.7 \%$ of 162 primigravidae had conceived within a year of marriage.

Diddle et al. (1947), working among families in the U.S. armed Forces at Key West, Florida, surveyed 1,192 women, of whom 799 were pregnant. Of these latter, 261 were primigravidae about whom there were full data, including coital rates. They found that $190(72.7 \%)$ of them conceived within six months and 226 (or $86.8 \%$ ) had conceived within one year. By two years $249(95.4 \%)$. had conceived. Bender (1952) found that of 714 primigravidae seen $77.4 \%$ had conceived within one year of first coitus or marriage, and $86.7 \%$ within two years. Tietze et al. (1950), reviewing the time required for conception in 1,727 pregnancies, found that more than $90 \%$ had conceived within one year. These surveys bear out the findings in Salford, and indicate that if pregnancy has not occurred within twelve months of the desire to conceive then the couple should be investigated on the grounds of infertility.

\section{Discussion}

A major factor influencing conception in women with normal genital tracts is that coitus between a fertile male and an ovulating female should take place at the time of ovulation (or, it may be, that in some cases it should be able to initiate ovulation). Barton and Wiesner (1940) thought that the ovum is viable only for about 24 hours. Hotchkiss (1945) believed that the spermatozoon is capable of fertilizing the ovum only for 24 to 72 hours after ejaculation into the posterior fornix of the vagina. These two facts means that a woman is capable of conceiving on only three days of each month, or a maximum of 39 days a year. The important thing is when coitus occurs, not how often.

Davis (1929) investigated the sexual habits of 971 women, and found that, on an average, coitus takes place twice nightly in the first three months of marriage, once nightly in the first year, and twice weekly in the first three years. Thus in the first year of marriage the average woman will have the maximum opportunity of conceiving. After the first years the frequency of coitus is dropping and pregnancy becomes less likely. This may be, in part, the explanation of lowered fertility indices which are said to occur (see above) as a woman grows older.

That psychosomatic factors may influence fertility has long been recognized. Stallworthy (1948) asks, "Is it not probable that a woman may deprive herself of the conception she desires because of the very strength of the desire or the fear of it?" "Hysteria" may produce tubal spasm (Stallworthy), changes in the cervical mucus (Barton and Wiesner, 1945-6), premature maturation of the follicles and discharge of unripe ova (Dunbar, 1946), and possibly anovulation.

Is it not possible, as the months go by and the longdesired conception remains unfulfilled, that this tension mounts and manifests itself in many ways-in general psychological disturbances, in frigidity (and thus in less frequent coitus), and in marital upsets? And from this it is but a short step to the establishment of the vicious circle of "hysteria "-absence of conception-" hysteria."

There is far more to the investigation of a barren marriage than the finding of a "potent male and patent tubes."

\section{Conclusion and Summary}

In a survey of 1,202 primigravidae attending Hope Hospital, Salford, between August, 1950, and June, 1951, it was found that $90.25 \%$ had conceived within a year of so desiring. Evidence is brought forward which suggests that many cases of infertility are due to as yet inexplicable psychosomatic factors. It is suggested that many of these factors can be corrected by simple investigation and reassurance of the infertile couple. Since only $4 \%$ more women conceive between 12 and 24 months after deciding to have a baby than do within the first year, it seems reasonable to investigate infertile couples as soon as one year has passed without pregnancy occurring.

The advantages of this earlier investigation are that (1) the psychosomatic factors involved can be tackled earlier : (2) the sexual drive is greater in the earlier years of marriage ; (3) both sexual drive and psychosomatic factors are probably aggravated by non-conception; (4) minor anatomical defects can be remedied earlier; (5) if an absolute bar to conception exists adoption of 
a child can be made earlier; (6) the investigation of infertile couples extends over many months.

My thanks are due to the medical and nursing staff of the obstetrical and gynaecological department of Hope Hospital, Salford, for their help in the preparation of this paper.

\section{REFERENCES}

Barton, M., and Wiesner, B. P. (1945). Lancet, 1, 663.

British Medical Journal, 2, 606.

Bender, S. (1952). Ibid., 2, 409.

Davis, K. B. (1929). Factors in the Sex Life of 2,000 Women. New York. Diddle, A. W Jack, R. W. and Pearse, R. L. (1947). Amer. J. Obstet. Gynec. 54, 57.

Dunbar, H. F. (1946). Emotions and Bodily Changes. Columbia Univ. Press, New York.

Duncan, M. (1866). Fecundity, Fertility, and Sterility. London.

Hotchkiss, R S (1945). Fertility in Men Heinemann, London.

Meaker, S. R. (1934), Human Sterility. New York.

Royal Commission on Population (1949). Vol. 1: Family Limitation. London.

Pearl, R. (1939). The Natural History of Population. London.

Russell, C. S. (1946). Lancet, 1, 300

Stallworthy, I (1948). J Obstet, Gynaec Brit Emp. 55, 171

Tietze, C., Guttmacher, A. F., and Rubin, S. (1950). Fertil. and Steril., 1, 338 .

\section{"COLIFORM DIARRHOEA" IN ADULT hOSPITAL PATIENTS}

\author{
BY
}

William McNAUght, M.B., Ch.B.

AND

JOHN S. STEVENSON, M.D.

(From the Department of Bacteriology, Stobhill General Hospital, Glasgow)

This report contains the results of an investigation of adults' faeces for the presence of those type-specific coliform organisms known to be closely associated with diarrhoea and vomiting in infants. The work was undertaken as an extension of two smaller investigations previously reported by Stevenson $(1950,1952)$, who described the isolation of Bact. coli O111.B4 (D433) from adults.

Most of the published work on type-specific strains of Bact. coli concerns their presence in the faeces of infants ; their occurrence and effects in the adult have not yet been fully studied. Fourteen cases of diarrhoea in adults from whom Bact. coli O111.B4 was isolated were reported by Stevenson (1950), and Kirby, Hall, and Coackley (1950) described enteritis in adult volunteers, caused by drinking milk inoculated with an organism of the same type-specific group. Stevenson (1952) investigated specimens of faeces from more than 1,000 adults and found Bact. coli O111.B4 in nine, four of whom had diarrhoea. Further evidence that this coliform can produce intestinal upset in the adult was provided by Ferguson and June (1952), who described a large-scale experiment in which adult males developed enteritis following the ingestion of milk artificially infected with the organism.

The six strains of Bact. coli from which antisera were prepared and used in the present investigation have been described by Taylor and Charter (1952) and Charter and Taylor (1952). They are designated at present as follows : Bact. coli O111.B4, O55.B5, O26.B6, Canioni, E611, and E990.

\section{Methods and Results}

The investigation covered the period October, 1951, to October, 1952. At the outset, $O$ and $O B$ antisera were prepared to Bact. coli strains O111.B4, O55.B5, and O26.B6; a "pooled" serum was made, and was checked before use. In March, 1952, the strains Bact. coli Canioni, E611, and E990 became available; individual and pooled sera were also prepared from these strains. Thus three type-specific antisera were available for the first six months and six antisera for the second six months of the investigation.

The faecal specimens, most of which were from cases of diarrhoea, were inoculated on to MacConkey, D.C.A., and Difco "SS" agar plates and into a "selenite F" enrichment broth. The subsequent growth on the MacConkey plate was used to detect type-specific coliform strains by slide agglutination; final identification of the organisms was made by tube-testing for the $\mathrm{O}$ and $\mathrm{B}$ antigens. The other media were employed to detect the Salmonella and Shigella groups. Each MacConkey plate was examined by testing the inoculation "well" and five separate colonies with the two pooled sera; positive colonies were checked against individual sera and subcultured for tube agglutination tests.

The figures obtained over the twelve-months period are summarized in Table I. Shigella and Salmonella results

Table I.-Results of Examination of 894 Adult Stools

\begin{tabular}{c|c|c|c|c|c|c|c|c}
\hline \multicolumn{6}{c|}{ Type-specific Strains of Bact. coll Isolated } & Shigella & $\begin{array}{c}\text { Salmonella } \\
\text { Isolated }\end{array}$ \\
\hline Total & $\begin{array}{c}\text { O111 } \\
\text { B4 }\end{array}$ & $\begin{array}{c}\text { O55 } \\
\text { B5 }\end{array}$ & $\begin{array}{c}\text { O26 } \\
\text { B6 }\end{array}$ & E611 & E990 & Canioni & & \\
\hline 15 & 5 & 2 & 8 & 0 & 0 & 0 & 16 & 4 \\
\hline $1.7 \%$ & $0.6 \%$ & $0 \cdot 2 \%$ & $0.9 \%$ & - & - & - & $1.8 \%$ & $0.4 \%$ \\
\hline
\end{tabular}

TABLE II.-Analysis of Cases

\begin{tabular}{|c|c|c|c|c|}
\hline $\begin{array}{l}\text { Case } \\
\text { No. }\end{array}$ & $\begin{array}{l}\text { Age and } \\
\text { Sex }\end{array}$ & Clinical Notes & $\begin{array}{c}\text { Organism } \\
\text { Isolated }\end{array}$ & $\begin{array}{l}\text { Type of } \\
\text { Case }\end{array}$ \\
\hline 1 & F 20 & Nurse in children's wards. & $\begin{array}{l}\text { O55.B5 } \\
19 / 10 / 51\end{array}$ & Sporadic \\
\hline 2 & F 64 & $\begin{array}{l}\text { Senile dementia. Sharp attack } \\
\text { of diarrhoea. Death }\end{array}$ & $\begin{array}{l}\mathrm{O} 26 . \mathrm{B} 6 \\
22 / 11 / 51\end{array}$ & ," \\
\hline 3 & F 52 & $\begin{array}{l}\text { Abdominal adhesions. Diar- } \\
\text { rhosa }\end{array}$ & O26.B6 & " \\
\hline 4 & M 51 & Early ulcerative colitis $\quad \ldots$ & $\begin{array}{r}026 \mathrm{~B} 6 \\
8 / 1 / 52\end{array}$ & ," \\
\hline 5 & M 46 & Pleural effusion. Diarrhoea .. & O26. B6 & \\
\hline 6 & M 68 & Pulmonary tuberculosis. Diar- & $\begin{array}{l}\text { O26.B6 } \\
20 / 5 / 52\end{array}$ & Wa \\
\hline 7 & M 50 & $\begin{array}{l}\text { Acute rheumatism. No diar- } \\
\text { rhoea }\end{array}$ & $\begin{array}{l}\text { O26.B6 } \\
20 / 5 / 52\end{array}$ & outbreak \\
\hline 8 & M 67 & $\begin{array}{l}\text { Pulmonary tuberculosis. Diar- } \\
\text { rhoea }\end{array}$ & $\begin{array}{l}\text { O26.B6 } \\
21 / 5 / 52\end{array}$ & \\
\hline 9 & M 79 & $\begin{array}{l}\text { Gangrene of leg. Amputation. } \\
\text { Good recovery. Diarrhoea } \\
\text { and vomiting. Death }\end{array}$ & $\begin{array}{l}\text { O111.B4 } \\
27 / 5 / 52\end{array}$ & Sporadic \\
\hline 10 & F 59 & $\begin{array}{c}\text { Glaucoma. Diabetes. Diar- } \\
\text { rhoea }\end{array}$ & $\begin{array}{l}\text { O111.B4 } \\
29 / 5 / 52\end{array}$ & \\
\hline 11 & F 73 & Senility. Diarrhoea .. $\quad$. & $\underset{3 / 6 / 52}{\text { O111.B4 }}$ & Ward \\
\hline 12 & F 84 & Senility. No diarrboea $\quad \ldots$ & $\underset{8 / 6 / 52}{O 111 . \bar{B} 4}$ & outbreak \\
\hline 13 & F 66 & Hypertension. No diarrhoea & O111.B4 & \\
\hline 14 & F 26 & Mitral stenosis. Diarrhoea .. & $\begin{array}{l}\text { O26.B6 } \\
10 / 9 / 52\end{array}$ & Sporadic \\
\hline 15 & F 22 & $\begin{array}{l}\text { Diarrhoea and vomiting for } \\
24 \text { hours }\end{array}$ & $\begin{array}{l}\text { O55.B5 } \\
27 / 10 / 52\end{array}$ & " \\
\hline
\end{tabular}

have been added to the table for comparison, but no member of these two groups was isolated from any of the cases yielding type-specific coliforms. A brief analysis of the cases is shown in Table II.

\section{Description of Cases}

Case 1.-An otherwise healthy nurse aged 20 reported sick with diarrhoea on October 18, 1951. Next day Bact. coli O55.B5 was isolated. She had been employed in a paediatric ward in which were cases of gastro-enteritis, none of whom was known to be associated with Bact. coli O55.B5. Rectal swabs were taken from all the infants in the ward concerned, and Bact. coli O55.B5 was isolated from a male infant aged 5 months who was convalescing from gastro-enteritis associated with Bact. coli O111.B4, but who at this point had no gastro-intestinal symptoms. The nurse made an uneventful recovery within a few days; the baby remained symptomless.

Case 2.-A woman aged 64 had been an in-patient for one year and suffered from senile dementia. There 